\section{Analisis Pengendalian Intern Atas Sistem Informasi Penjualan Terhadap Efektivitas Dan Efisiensi Penjualan (Studi Kasus Pada PT. Enseval Putera Megatrading Tbk.)}

\author{
Ilham Firmansyah dan Udi Pramiudi \\ Program Studi Akuntansi, Institut Bisnis dan Informatika Kesatuan \\ Bogor, Indonesia \\ E-Mail: ilham.fsh@gmail.com
}

Internal Control in

Sales Information

System

\begin{abstract}
As one form of organization, the company must have goals and objectives to be achieved. Sales accounting information system is one of the accounting information sub systems that explains how the procedures in carrying out sales activities. To realize the management of company activities effectively, efficiently, and internal controls are needed that can provide accurate and trustworthy information. To fulfill this, there are several elements which are the main characteristics of an internal control system, including; organizational structure that separates functional responsibilities appropriately, the existence of a system of authority and good bookkeeping procedures, sound practices must be carried out in carrying out the duties and functions of each section in the organization as well as the existence of an employee skill level in accordance with their responsibilities. The results of internal control research on the sales system owned by PT. Enseval Putera Megatrading Tbk. it is quite good and adequate, which includes elements of: control environment, risk assessment, healthy practices, employees whose quality is in accordance with their responsibilities, information and communication, and monitoring. The Role of Internal Control of the sales information system in increasing sales effectiveness and efficiency is very important. The internal sales control system implemented is effective, because it reached the 2018 sales target of Rp. 21.7 trillion, and the realization of the 2018 budget of Rp. 20.6 trillion ( \pm 94.93\%) and sales volume increased. Can be seen from the increase in sales volume in 2017 amounting to Rp. 19,669,096,571,146 while in 2018 the amount of Rp. 20,604,487,293, 751.
\end{abstract}

Keywords : internal control, sales information system, sales effectiveness and efficiency

\title{
PENDAHULUAN
}

Pada perusahaan yang berorientasi untuk mendapatkan laba, penjualan merupakan kegiatan utama untuk mencapai tujuan utama. Seiring perkembangan teknologi saat ini, penerapan sistem informasi akuntansi merupakan suatu keharusan untuk memperlancar aktivitas-aktivitas dalam perusahaan agar pelaksanaannya dapat lebih cepat, tepat, akurat dan efisien. Menurut Mulyadi (2016:2) mendefinisikan bahwa Sistem adalah sekelompok unsur yang erat berhubungan satu dengan yang lainnya, yang berfungsi bersama-sama unuk mencapai tujuan tertentu.

Sistem informasi akuntansi penjualan merupakan salah satu sub sistem informasi akuntansi yang menjelaskan bagaimana prosedur dalam melakukan kegiatan penjualan. Ada beberapa manfaat sistem informasi akuntansi penjualan, yaitu menyediakan informasi yang akurat dan tepat. Meningkatnya efisiensi dan memeberikan dampak terhadap pendapatan dan meningkatnya kemampuan perusahaan dalam mengambil keputusan dengan bijak. Dalam sistem penjualan ini akan memberitahukan kepada para pengguna informasi tentang bagaimana kegiatan tersebut dilaksanakan, dokumen apa saja yang diperlukan, serta pihak yang mana saja yang berwewenang mengotorisasi kegiatan penjualan. Untuk mewujudkan pengelolaan aktivitas-aktivitas perusahaan

\section{JIAKES}

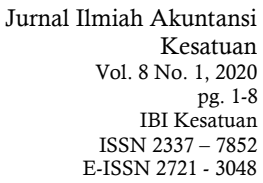


Internal Control in Sales Information System

2

secara efektif, efisien, dan dibutuhkan adanya pengendalian intern yang dapat memberikan informasi yang akurat dan dapat dipercaya. pengendalian intern merupakan kebijakan dan prosedur yang melindungi harta organisasi dari kemungkinan penyalahgunaan, memastikan bahwa informasi telah disajikan secara akurat dan memastikan bahwa peraturan telah dipatuhi sebagaimana mestinya.

Menurut Ardana dan Lukman $(2016,75)$ definisi yang dirumuskan oleh Committee of sponsoring organizations (COSO) of the Treadway Commission, (1994) adalah suatu proses yang diberlakukan oleh dewan direksi, manajemen, dan aparat lainnya, yang dirancang untuk memberikan keyakinan yang memadai sehubungan dengan pencapaian tujuan dalam kategori sebagai efektivitas dan efisiensi operasi, keandalan laporan keuangan, dan ketaatan terhadap hukum dan peraturan yang berlaku. Dalam penelitian Kholidah (2017) secara keseluruhan pelaksanaan sistem informasi akuntansi penjualan berpengaruh terhadap pengendalian intern. Penelitian Robi Maulana (2015) dikatakan bahwa Sistem informasi akuntansi berpengaruh signifikan terhadap efektivitas pengendalian internal. Begitu juga dengan penelitian Dedi Karmana (2017) sistem informasi akuntansi penjualan kredit yang dilaksanakan mempunyai peranan besar dalam menunjang efektivitas pengendalian intern penjualan kredit

Berdasarkan latar belakang diatas maka penulis akan mengidentifikasi dan merumuskan permasalahan yang akan dibahas sebagai berikut : (1) Bagaimana penerapan pengendalian intern pada sistem informasi penjualan pada PT Enseval Putera Megatrading? (2) Bagaimana peranan pengendalian intern pada sistem informasi penjualan terhadap efektivitas dan efisiensi penjualan pada PT Enseval Putera Megatrading?

\section{TINJAUAN PUSTAKA}

\section{Sistem Informasi Akuntansi}

Menurut Mulyadi $(2016,3)$ sistem informasi akuntansi adalah organisasi formulir, catatan dan laporan yang dikoordinasi sedemikian rupa untuk menyediakan informasi keuangan yang dibutuhkan oleh manajemen guna memudahkan pengelolaan perusahaan. Tujuan umum pengembangan sistem akuntansi adalah sebagai berikut: Untuk menyediakan informasi bagi pengelolaan kegiatan usaha baru, Untuk memperbaiki informasi yang dihasilkan oleh sistem yang sudah ada, baik mengenai mutu, ketetapan penyajian, maupun struktur informasinya dan Untuk memperbaiki pengendalian akuntansi dan pengecekan internal. Akuntansi merupakan alat pertanggung jawaban kekayaan suatu organisasi.

\section{Penjualan}

Menurut Abdullah dan Tantri $(2016,3)$ penjualan adalah bagian dari promosi dan promosi adalah salah satu bagian dari keseluruhan sistem pemasaran. Penjualan adalah ilmu dan seni mempengaruhi pribadi yang dilakukan penjual untuk mengajak orang lain agar bersedia membeli barang atau jasa yang ditawarkan untuk memperoleh keuntungan yang dapat meningkatkan penghasilan

\section{Sistem Informasi Akuntansi Penjualan}

Sistem penjualan digunakan untuk menangani transaksi penjualan barang atau jasa, baik secara kredit maupun secara tunai. Dalam transaksi penjualan kredit, jika order dari pelanggan telah dipenuhi dengan pengiriman barang atau penyerahan jasa untuk jangka waktu tertentu perusahaan memiliki piutang kepada pelanggannya. Dalam penjualan tunai, barang atau jasa baru diserahkan oleh bagian pengiriman kepada pembeli jika bagian kasir telah menerima uang dari pembeli. Menurut Mulyadi (2016, 174) catatan yang digunakan adalah: Jurnal Penjualan, Kartu Piutang, Kartu Persediaan, Kartu Gudang, Jurnal Umum

\section{Pengendalian Internal}

Menurut Ardana dan Lukman $(2016,75)$ definisi yang dirumuskan oleh Committee of sponsoring organizations (COSO) of the Treadway Commission, (1994) adalah sebagai berikut: 
..... as process, effected by an entity's board of directors, management and other personnel, designed to provide reasonable assurance regarding the achievement of objectives in the following categories: (a) effectiveness and eficiency operation, (b) reliability of financial reporting, (c) compliance with applicable laws and regulations. (..... suatu proses yang diberlakukan oleh dewan direksi, manajemen, dan aparat lainnya, yang dirancang untuk memberikan keyakinan yang memadai sehubungan dengan pencapaian tujuan dalam katregori sebagai berikut: (a) efektivitas dan efisiensi operasi, (b) keandalan laporan keuangan, dan (c) ketaatan terhadap hukum dan peraturan yang berlaku.
Internal Control in Sales Information System

\section{Unsur Pengendalian Internal}

Menurut Mulyadi $(2016,176)$ unsur pengendalian internal yang diterapkan dalam sistem penjualan kredit : Organisasi, Sistem Otorisasi dan Prosedur Pencatatan serta Praktik yang Sehat

\section{Efektif dan Efisien}

Menurut Hans Kartikahadi (1990) efektivitas dimaksud bahwa produk akhir suatu kegiatan operasi telah mencapai tujuannya baik ditinjau dari segi kualitas kerja, kuantitas hasil kerja maupun batas waktu yang ditargetkan. Efisiensi berarti bertindak dengan cara yang dapat meminimalisasi kerugian atau pemborosan sumber daya dalam melaksanakan atau menghasilkan sesuatu.

\section{METODOLOGI PENELITIAN}

Penelitian ini merupakan penelitian deskriptif kualitatif. Data primer diperoleh langsung melalui observasi dan wawancara dengan pihak yang berwenang serta data fisik dokumen mengenai permasalahan yang hendak diteliti. Data Sekunder diambil secara tidak langsung dari sumbernya dan data tersebut telah diolah lebih lanjut. Waktu dan tempat penelitian dilaksanakan pada bulan April 2019 dan tempat penelitian dilaksanakan di PT Enseval Putera Megatrading Tbk. di J1. Raya Wangun No.216, Sindangsari, Kec. Bogor Timur, Kota Bogor, Jawa Barat 16146.

\section{HASIL DAN PEMBAHASAN}

\section{Sistem Informasi Penjualan Pada PT. Enseval Putera Megatrading Tbk.}

Mayoritas penjualan PT Enseval Putera Megatrading Tbk. dilakukan secara kredit. Transaksi penjualan diawali dari pihak salesman membuat surat order pembelian yang menerima orderan dari pihak pelanggan. Kemudian surat order tersebut diproses hingga menjadi faktur penjualan yang akan dikirimkan bersama dengan barang tersebut kepada pelanggan. PT Enseval Putera Megatrading telah menggunakan suatu software yang digunakan dan juga diaplikasikan untuk membantu melakukan manajemen dari sebuah database alias basis data dari suatu perusahaan atau instansi, dan menerapkan serta mengimplementasikan database tersebut ke dalam sistem komputer, yaitu Software ORACLE. Keungguilan Database Oracle : Memiliki kemampuan yang baik untuk melakukan manajemen sistem database, Jumlah data dan juga angka yang diakomodir sangat besar, Dapat mengolah data dengan cepat dan akurat, Memiliki kemampuan untuk melakukan cluster server, Dapat melakukan management User, Multi-Platform, Pemprosesan data yang cepat dan Memiliki kemampuan historical.

\section{Prosedur Penjualan PT. Enseval Putra Mega Trading}

1. Bagian salesman Pada bagian salesman menerima order, menginput order menggunakan PDA (Personal Digital Asistance), PDA berfungsi untuk menyimpan alamat dan nomor telepon, mengatur jadwal kegiatan, kalender dan menyimpan catatan. Jika sesuai maka orderan yang sudah dimasukkan ke dalam PDA secara otomatis akan masuk ke dalam sistem Oracle

2. Bagian SSD (Sales Support Direktorat) Bagian SSD menerima order yang masuk secara otomatis kedalam sistem oracle dari bagian salesman beserta dokumen Sales 
Internal Control in

Sales Information

System

$\underline{4}$
Order (SO) rangkap 2 kemudian memeriksa stok barang yang diorder oleh outlet atau pelanggan jika stok barang tersebut tidak ada maka di sampaikan kepada bagian salesman, untuk stok barang yang ada diinput dan akan diperiksa syaratnya oleh bagian FSS/DM (Field Sales Supervisor) apakah sesuai atau tidak, dan mengecek harga, diskon, order secara tunai kredit dan mencetak Sales Order (SO).

3. Bagian FSS/DM (Field Sales Supervisor/Distrik Manager). Pada bagian ini memeriksa syarat, syarat yang dimaksud yaitu kondisi piutang, over limit atau batas kredit jika syarat tersebut sesuai maka bagian KSA melampirkan dokumen Sales Order (SO) dan selanjutnya akan diproses pada sistem, sedangkan untuk syarat yang tidak memenuhi maka akan dibuatkan keputusan apakah order tetap ditolak atau diperiksa terlebih dahulu berdasarkan piutang. Jika keputusan ditolak maka dibuatkan perintah pembatalan order ke admin.

4. Bagian KABAG atau KSA (Kepala Bagian atau Kepala Seksi Akuntansi)/ABM (Area Businnes Manager) Pada bagian ini jika keputusan order secara kredit dan sesuai dengan syarat akan dilakukan pemeriksaan piutang. Jika berdasarkan pemeriksaan piutang telah sesuai akan di proses melalui sistem sedangkan jika tidak sesuai dilakukan pembatalan order ke admin.

5. Bagian Data Proses. Bagian data proses yaitu memproses data order yang telah sesuai dengan orderan dari pelanggan dan penyiapan barang sampai barang tersebut siap dikirim.

Pengendalian Internal atas penjualan PT. Enseval Putera Megatrading Tbk

Pengendalian internal PT. Enseval Putera Megatrading dapat dilihat sebagai berikut.

1. Lingkungan Pengendalian; mencerminkan suasana perusahaan yang mempengaruhi sikap dan tindakan para anggota perusahaan akan pentingnyapengendalian dan menentukan arah perusahaan serta memengaruhi kesadaran pengendalian pihak manajemen dan karyawan. Hal-hal lingkungan pengendalian yang dijalankan oleh PT Enseval Putera Megatrading Tbk:

a. Integritas dan nilai etika; Setiap karyawan memiliki hubungan baik dan solidaritas yang tinggi, mereka saling membantu bekerjasama dalam melakukan pekerjaannya. Hubungan antara atasan dan bawahan juga sangat erat mereka selalu berkomunikasi di dalam menyelesaikan suatu masalah. Etika perusahaan pada PT Enseval Putera Megatrading sangat diperhatikan, terutama dalam kegiatan penjualan dalam menerima order, menagih piutang kepada pelanggan telah ditetapkan agar memberikan kenyamanan kepada pihak pelanggan.

b. Struktur Organisasi. Struktur organisasi pada PT Enseval Putera Megatrading Tbk telah menunjukkan garis otorisasi dan tanggung yang disusun dengan jelas, sehingga tidak ada tugas rangkap yang memungkinkan terjadinya penyimpangan. Dari struktur organisasi yang ada tersebut setiap karyawan telah diberikan wewenang dan tanggung jawabnya masing-masing atas posisi yang ditempatinya.

c. Sistem Otorisasi dan prosedur pencatatan. Sistem otorisasi dan prosedur pencatatan harus diotorisasi oleh pihak berwenang untuk menunjukkan keabsahan dokumen. Untuk setiap pencatatan pada PT Enseval Putera Megatrading Tbk dilakukan dengan menggunakan sistem yang terkomputerisasi. Sistem otorisasi dan prosedur pencatatan penjualan diciptakan untuk menunjang terwujudnya pengendalian internal yang memadai.

2. Penilaian Resiko. PT. Enseval Putera Megatrading Tbk. telah melakukan beberapa upaya pencegahan terjadinya resiko dalam proses penjualan. Pencegahan yang dilakukan oleh perusahaan adalah dengan melakukan pemeriksaan terlebih dahulu terhadap pelanggan yang akan melakukan pembelian barang pada PT. Enseval Putera Megatrading Tbk. Para pelanggan akan diperiksa oleh bagian akuntansi mengenai performance-nya. Tahap ini dapat mengurangi tingkat kerugian yang mungkin akan diderita oleh perusahaan dikarenakan banyaknya piutang yang tak tertagih. 
3. Praktik yang sehat. Menurut teori, praktik yang sehat pada sistem penjualan adalah faktur penjualan yang bernomor urut tercetak dan pemakaiannya dipertanggung jawabkan oleh fungsi penjualan. PT Enseval Putera Megatrading Tbk dalam menjalankan kinerjanya telah dapat dikatakan menjalankan praktik yang sehat. Penggunaan faktur penjualan telah bernomor urut tercetak. Setiap penjualan dimulai dari order pemesanan, pada bagian salesman memberikan dokumen pendukung dengan nomor faktur yang jelas dan adanya otorisasi dari bagian kredit yang nantinya dapat ditelusuri dan bisa diminta pertanggung jawabannya.

4. Karyawan yang Mutunya Sesuai dengan Tanggung Jawabnya. Pada PT Enseval Putera Megatrading Tbk penarikan karyawan atau perekrutan karyawan dilakukan melalui seleksi berdasarkan persyaratan yang ditretapkan pada perusahaan bukan atas dasar hubungan kekeluargaan dan untuk pengembangan karyawan diadakannya training serta promosi jabatan.

5. Informasi dan komunikasi. Informasi dan komunikasi pada PT Enseval Putera Megatrading Tbk. tidak hanya digunakan untuk kejadian-kejadian internal saja, tetapi juga kejadian eksternal. Informasi-informasi tersebut dalam rangka pembuatan keputusan bisnis dan laporan eksternal.

6. Pemantauan pada PT. Enseval Putera Megatrading Tbk. langsung dilakukan oleh komite audit perusahaan agar sesuai dengan tugas dan tanggung jawab dari setiap bagian. PT Enseval Putera Megatrading Tbk. mengharuskan setiap cabangcabangnya untuk mengirimkan laporan kegiatan operasionalnya. Misalnya setiap bulan setiap cabang-cabang harus membuat atau menyusun laporan penjualan baik tunai maupun kredit dan kemudian mengirimkannya ke kantor pusat di cirebon yang bertujuan untuk memudahkan di dalam memonitoring kegiatan penjualan di cabangcabang.

Peranan Pengendalian Intern Pada Sistem Informasi Penjualan Terhadap Efektivitas Dan Efisiensi Penjualan Pada PT Enseval Putera Megatrading

Peranan Pengendalian intern sistem informasi penjualan pada PT Enseval Putera Megatrading Terhadap efektivitas dan efisiensi penjualan dapat dilihat dari beberapa komponen pengendalian intern, yaitu jika dilihat dari lingkungan pengendalian. Contohnya dalam pengendalian internal di PT. Enseval Putera Megatrading mereka mempunyai sikap sopan dalam menagih piutang. Karena jika sikap collector tidak sopan dan bahkan kasar maka pihak konsumen menjadi tidak bekerja sama, meminta waktu tambahan dan bahkan akan sembunyi jika pihak dari PT. Enseval Putera Megatrading yang berdampak menghambat pendapatan PT. Enseval Putera Megatrading Tbk. Dilihat juga dari struktur organisasi tidak adanya tugas rangkap yang memungkinkan terjadinya penyimpangan dan merugikan pendapatan. Sistem otorisasi dan prosedur pencatatan penjualan diciptakan untuk menunjang terwujudnya pengendalian internal yang memadai. Hal ini perlu dilakukan untuk menghindari kesalahan dan kecurangan yang mungkin terjadi disebabkan faktor internal. Dan dari Sistem otorisasi dan prosedur pencatatan yang baik akan meminimalisir terjadinya kesalahan perhitungan pencatatan.

Pada pengendalian praktik yang sehat, Penggunaan faktur penjualan telah bernomor urut tercetak. Setiap penjualan dimulai dari order pemesanan, pada bagian salesman memberikan dokumen pendukung dengan nomor faktur yang jelas dan adanya otorisasi dari bagian kredit yang nantinya dapat ditelusuri dan bisa diminta pertanggung jawabannya. Adanya pemeriksaan yang dilakukan secara mendadak terhadap pencatatan piutang. Dengan adanya pemeriksaan tersebut untuk menguji ketelitian catatan piutang yang diselenggarakan oleh fungsi yang bertanggung jawab karena untuk menghindari kesalahan yang akan merugikan perusahaan. Dan juga secara periodik akan melakukan rekonsiliasi antara saldo piutang di buku besar dengan saldo piutang pembantu.

Dilihat dari Karyawan yang Mutunya Sesuai dengan Tanggung Jawabnya. Suatu organisasi perusahaan bergantung pada karyawan dalam melaksanakan kegiatannya. Semakin banyak tuntutan pekerjaan dan semakin berkembangnya dunia usaha sehingga dibutuhkan karyawan yang mampu bersaing, terampil dan tanggung jawab
Internal Control in

Sales Information

System

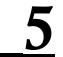


Internal Control in Sales Information System

terhadap pekerjaannya. Karena jika tidak akan membuang waktu dan biaya yang dikeluarkan bisa jadi tidak tepat sasaran serta akan merugikan perusahaan.

Prioritas utama PT Enseval didalam pengendalian internal sistem informasi penjualan adalah dari penilaian risiko yaitu pengendalian piutang. Karena faktor utama terjadinya sales pada PT. Enseval Putera Megatrading adalah dari piutang. Tahap ini dapat mengurangi tingkat kerugian yang mungkin akan diderita oleh perusahaan dikarenakan banyaknya piutang yang tak tertagih. Pencegahan yang dilakukan oleh perusahaan adalah dengan melakukan pemeriksaan terlebih dahulu terhadap pelanggan yang akan melakukan pembelian barang pada PT. Enseval Putera Megatrading Tbk. Para pelanggan akan diperiksa oleh bagian akuntansi mengenai performance-nya. Perusahaan akan menilai bagaimana saldo limit kreditnya, apakah sesuai dengan saldo kredit permintaan barang atau tidak lalu setelah itu dilihat bagaimana pembayaran piutang konsumen tersebut apakah lancar atau tidak. Karena jika tidak memnuhi syarat yang telah disebutkan akan ada pertimbangan dari kepala bagian akuntansi apakah disetujui atau tidak. Tetapi beda kasus dengan perusahaan retail besar yang sudah mempunyai nama seperti ramayana, giant dan lain-lain. Mereka ada penyesuaian khusus karena mereka sudah mempunyai cabang dimana-mana dan kondisi keuangannya hampir tidak mungkin akan mengalami bangkrut tetapi jika terjadi masalah dalam penagihan bisa dituntut ke jalur hukum.

Target anggaran penjualan dengan realisasi anggaran di PT. Enseval Putera megatrading Tbk. sudah cukup bagus dilihat bahwa persentasenya $( \pm 94,93 \%)$. Hal ini menunjukkan bahwa telah efektif karena realisasi penjualan sebesar 20,6 Triliun hampir mendekati target penjualan yang ingin dicapai yaitu sebesar 21,7 Triliun. Kenaikan penjualan juga dapat kita lihat di laporan keuangan yang tertera dilampiran. Pada tahun 2017 sales sebesar 19,66 T sedangkan pada tahun 2018 sales sebesar 20,60 T.

Tabel 1. Persentase target penjualan dengan realisasi penjualan PT. Enseval Putera Megatrading Tbk.

\begin{tabular}{|l|c|}
\hline Target Penjualan 2018 & 21.7 \\
\hline Realisasi Penjualan 2018 & 20.6 \\
\hline Persentase & $94,93 \%$ \\
\hline
\end{tabular}

Sumber: PT Enseval Putera Megatrading Tbk.

Tidak semua bisa menjadi konsumen dari perusahan ini, PT Enseval Putera Megatrading Tbk. tidak akan menjual kepada perorangan. Dan bahkan outlet atau apotik juga tidak bisa sembarangan. Perusahaan akan melihat apakah ada izin praktik atau tidak, ada pihak apoteker yg bertanggung jawab (berlisensi) atau tidak. Syarat pertama pengajuan kredit limit untuk konsumen baru kurang lebih 10 juta. Untuk penambahan saldo kredit limit dilihat dari performancenya apakah pembayarannya lancar atau tidak. Perusahaan akan melihat selama 3 bulan. Jika selama tiga bulan lancar akan diberikan kenaikan kredit limit yang bertahap sesuai kebijakan dari perusahaan.

Berdasarkan uraian diatas dapat diketahui bahwa pengendalian intern sistem informasi penjualan terhadap efektivitas dan efisiensi penjualan pada PT Enseval Putera Megatrading Tbk. telah berjalan dengan baik, karena telah sesuai dengan komponen pengendalian intern yaitu diantaranya lingkungan pengendalian, penilaian risiko, praktik yang sehat, karyawan yang mutunya sesuai tanggung jawabnya, informasi dan komunikasi, dan pemantauan. Dari hal - hal yang dijabarkan terlihat bahwa sistem pengendalian intern penjualan memegang pengaruh yang penting dalam menunjang efektivitas dan efisiensi penjualan. Karena baik tidaknya sistem pengendalian intern penjualan yang diterapkan sangat berpengaruh terhadap efektivitas dan efisiensi penjualan pada pada PT Enseval Putera Megatrading Tbk. Dan Target penjualan telah tercapai yaitu tahun 2018 sebesar Rp.21,7 triliun, realisasi anggaran tahun 2018 sebesar Rp. 20,6 triliun $( \pm 94,93 \%)$ dan terjadi peningkatan volume penjualan pada tahun 2017 sebesar Rp. 19.669.096.571.146 sedangkan tahun 2018 sebesar Rp. 20.604.487.293.751. 
Secara garis besar dari peningkatan volume penjualan dan target penjualan yang dicapai tersebut dapat dikatakan bahwa sistem pengendalian intern penjualan yang diterapkan pada PT. Enseval Putera Megatrading Tbk. berjalan secara efektif dan efisien, karena dapat mencapai target penjualan yang diharapkan.

\section{PENUTUP}

Adapun kesimpulan penelitian ini adalah:

1. Pengendalian intern penjualan yang dimiliki oleh PT. Enseval Putera Megatrading Tbk. sudah cukup baik dan memadai, yaitu yang mencakup unsur: diantaranya lingkungan pengendalian, penilaian risiko, praktik yang sehat, karyawan yang mutunya sesuai tanggung jawabnya, informasi dan komunikasi, serta pemantauan. Hal ini dapat dilihat dari adanya struktur organisasi dan job description yang jelas, dalam prosedur penjualan sudah ada pemisahan fungsi yang jelas antara yang melakukan penjualan, mengirimkan barang, melakukan penagihan, memberikan otorisasi atas penjualan kredit, membuat faktur penjualan dan melakukan pencatatan, sudah di gunakannya formulir-formulir yang bernomor urut tercetak dalam kegiatan penjualannya.

2. Peranan Pengendalian Intern sistem informasi penjualan dalam meningkatkan efektivitas dan efisiensi penjualan sangatlah penting. Sistem pengendalian intern penjualan yang diterapkan berjalan secara efektif, karena mencapai target penjualan tahun 2018 sebesar Rp.21,7 triliun, realisasi anggaran tahun 2018 sebesar Rp. 20,6 triliun $( \pm 94,93 \%)$ dan dan terjadi kenaikan volume penjualan. Dapat dilihat dari peningkatan volume penjualan pada tahun 2017 sebesar Rp. 19.669.096.571.146 sedangkan tahun 2018 sebesar Rp. 20.604.487.293.751.

\section{DAFTAR PUSTAKA}

Abdullah, Thamrin dan Tantri, Francis. 2012. Manajemen Pemasaran, PT. Raja Grafindo Persada, Depok.

Agoes, Sukrisno. 2017. Audit, Salemba Empat, Jakarta.

Ardana, I Cenik dan Lukman, Hendro. 2016. Sistem Informasi Akuntansi, Edisi 1, Mitra Wacana Media, Jakarta.

Fara, N., Dzulkirom, M., dan Husaini, A. 2015. Analisis Sistem Akuntansi Penjualan dan Penerimaan Kas Dalam Upaya Peningkatan Pengendalian Intern pada PT. Mitra Pinasthika Mustika Surabaya. Jurnal Administrasi Bisnis. Vol 26 (1).

Jaya, Hendry. 2018. Analisis Sistem Informasi Akuntansi Penjualan tunai dan Penerimaan Kas Dalam Meningkatkan Pengendalian Intern Pada PT. Puta Indo Cahaya Batam. Jurnal Akuntansi. Vol 12 (2).

Kamus Besar Bahasa Indonesia: https://kbbi.web.id. (Diakses pada tanggal 27 Juni 2019)

Karmana, Dedi. 2017. Peranan Sistem Informasi Akuntansi Penjualan Kredit Dalam Meningkatkan Efektivitas dan efisiensi Pengendalian Intern Penjualan Kredit pada PT Kerta Padalarang (Persero). Majalah Bisnis dan Iptek. Vol 10 (2).

Kholidah, N.D. 2017. Penerapan Sistem Informasi Akuntansi Penjualan Dalam Upaya Meningkatkan Pengendalian Internal PT. Dimensi Citra Semesta. Jurnal Ilmu dan Riset Akuntansi. Vol 6 (9).

Magribi, Robi Maulana. 2015. Pengaruh Sistem Informasi Akuntansi Terhadap Efektivitas Pengendalian Internal Penjualan pada PT. Arta Boga Cemerlang Cabang Majalengka. Jurnal Ilmiah Manajemen dan Akuntansi. Vol 2 (1).

Maulana, Robi. 2015. Pengaruh Sistem Informasi Akuntansi Terhadap Efektivitas Pengendalian Internal Penjualan pada PT. Arta Boga Cemerlang Majalengka. Jurnal Ilmiah dan Manajemen Akuntansi. Vol 2 (1).

Mulyadi. 2016. Sistem Akuntansi, Edisi 4, Salemba Empat, Jakarta.

Reeve, J.M., Warren, C.S., Duchac, Jonathan, E. 2009. Pengantar Akuntansi, Salemba empat, Jakarta.
Internal Control in Sales Information System

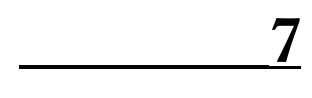


Internal Control in Sales Information System
Rudianto.2012. Pengantar Akuntansi, Erlangga, Jakarta.

Romney, Marshal B. dan Steinbart, Paul John. 2014. Sistem Informasi Akuntasi, Edisi 13, Salemba Empat, Jakarta.

Tampubolon, N.A., dan Hamta, Firdaus.2017. Penerapan Sistem Informasi Akuntansi Penjualan Dalam Menunjang Pengendalian Intern PT. Kita Jaya Sukses Batam. Jurnal Akuntansi. Vol 11 (2).

Wikipedia Bahasa Indonesia: https://id.wikipedia.org. (Diakses pada tanggal 27 Juni 